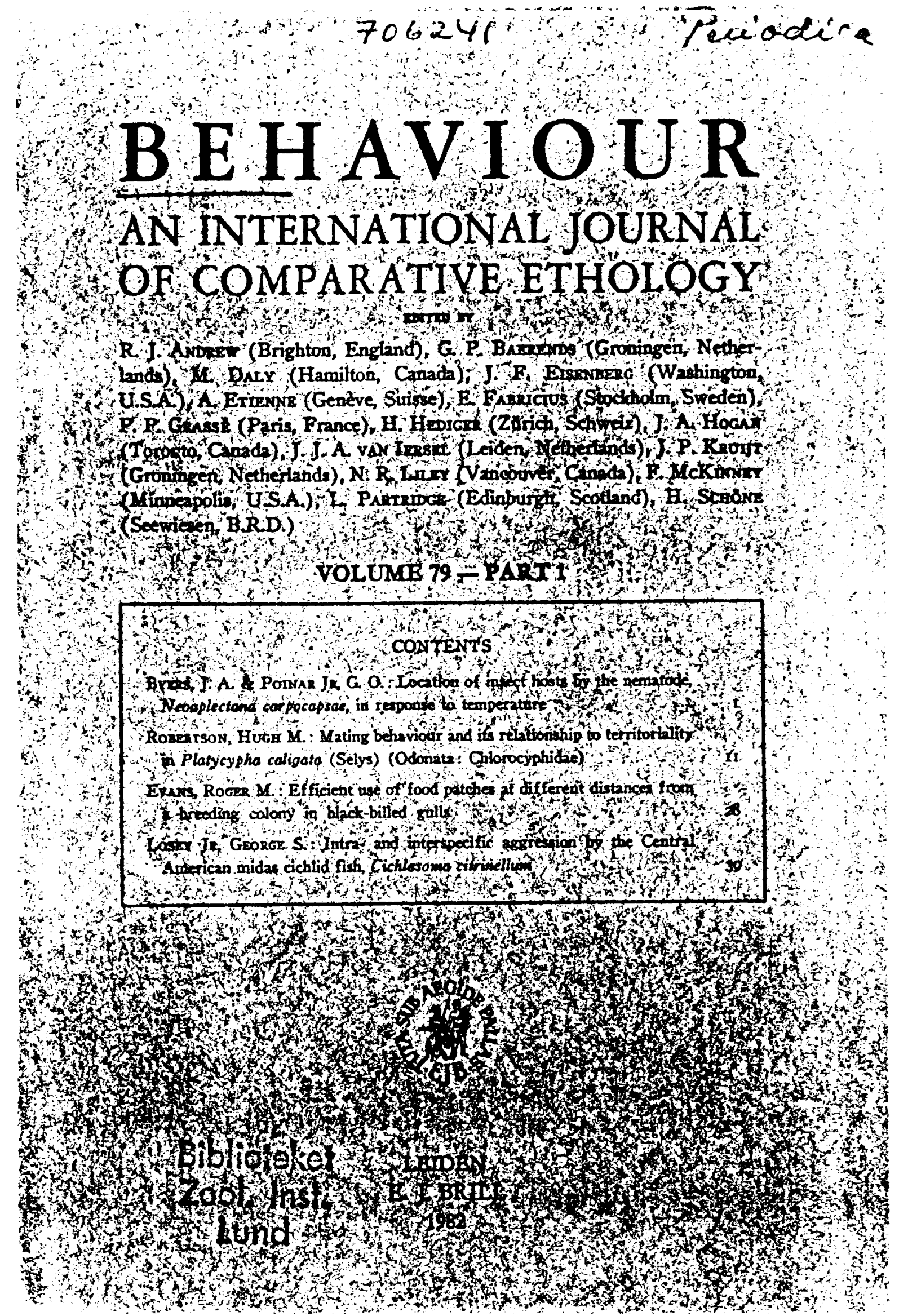




\title{
LOCATION OF INSECT HOSTS BY THE NEMATODE, NEOAPLECTANA CARPOCAPSAE, IN RESPONSE TO TEMPERATURE
}

\author{
by \\ J. A. BYERS') and G. O. POINAR Jr \\ (Department of Entomological Sciences, University of California, Berkeley, \\ Calif., U.S.A.) \\ (With 4 Figures) \\ (Acc. 5-IX-1981)
}

\section{INTRODUCTION}

The nematode, Neoaplectana carpocapsae Weiser (Nematode: Steinernematidae), has a very broad range of insect hosts encompassing numerous species and genera in practically all major orders (PoINAR, 1979). Many insect species can be infected with the nematode in the laboratory but in nature only those insects which spend part of their life cycle in the soil or other protected moist habitats are potential hosts. The nematode also has a wide geographical distribution occurring as "strains" in various areas of Europe and North America (Poinar, 1979). High numbers of infective third stage or "dauer" juveniles leave the insect cadaver and actively "search" for a new host. This dauer form can survive many months in the soil before finding a new host. Once an insect is located, the nematode can enter via the spiracles, mouth or anus. After reaching the body cavity, a symbiotic bacterium, Xenorhabdus nematophilus, is released causing death of the insect in 1-2 days (PoINAR \& Thomas, 1966; Poinar, 1979; Thomas \& Poinar, 1979). Several chemosensory theories of host location have been proposed for $N$. carpocapsae (Schmidt \& AlL, 1978, 1979; Gaugler et al., 1980). On the other hand, since insects in the soil lose very little heat by evaporation, their body temperature may rise a "few degrees above ambient" due to metabolic processes (KoIDsumI, in Bursell, 1974). The present study was conducted to determine if $N$. cacarpocapsae responds to subtle increases of temperature above ambient as part of the mechanism of host location.

1) Present address: Department of Animal Ecology, University of Lund, S-22362 Lund, Sweden. 


\section{METHODS}

The Breton strain of $N$. carpocapsae was reared in larvae of the greater wax moth, Galleria mellonella (L.) (WHrre, 1929). Newly emerged dauer nematodes were stored at room temperature (about $20^{\circ} \mathrm{C}$ ) on moistened filter paper for 2 weeks until used in the experiments. Nematodes were placed in the center of petri dishes filled with $35 \mathrm{ml}$ of $1 \%$ ion agar (Difco) to determine their response to various heat sources (Fig. 1) under several different ambient temperatures (Tables 1 and 2). After 24 hours in various experiments under certain ambient temperatures, the number of nematodes aggregating at the periphery of the dish in response to either the $4 \times 2 \times 6 \mathrm{~mm}$ long IR-LED, infra-red light emitting diode (no visible light, $9000 \AA$ ) ) or 0.25 watt resistor was recorded (Tables 1 and 2). The wall of each petri dish was divided into $26,1-\mathrm{cm}$ sections of which one length (Table 1) or two lengths on opposite sides (Table 2) included the heat source. Ten areas were selected at random from the non-heated sections and used for comparison to nematode aggregations in the heated areas ( $t$-tests). In another experiment (two replicates), a last instar larva of $G$. mellonella was taped on the underside of the petri dish and the number of nematodes aggregating within the agar above the wax moth body was recorded in $10 \mathrm{~mm}^{2}$ quadrants for comparison to peripheral quadrants about 4-5 mm away from the body outline (t-tests).

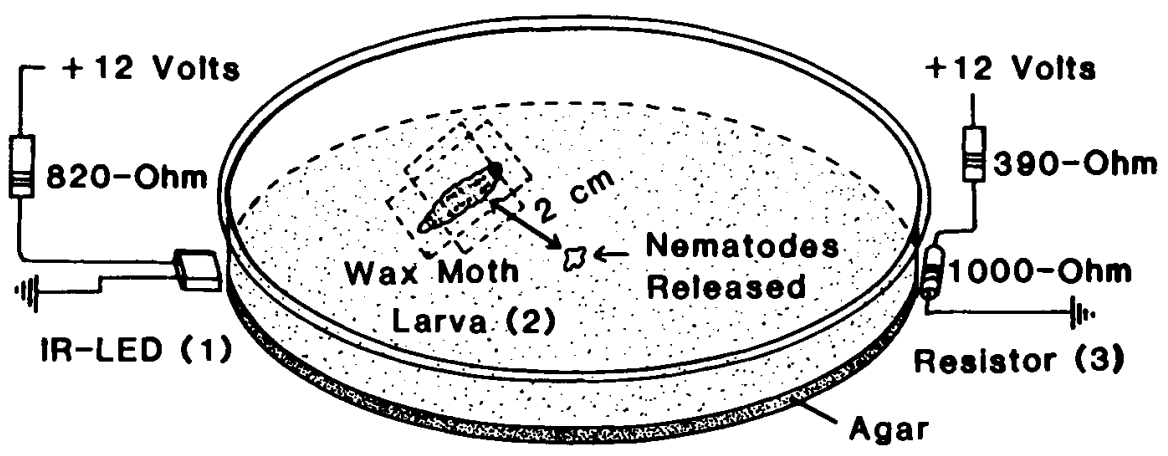

Fig. 1. Diagram of test arena showing the three types of experiments. From 1,000 to 2,000 nematodes were placed in a $0.5 \mathrm{~cm}$ diam. area at the center of a $8.5 \mathrm{~cm}$ plastic petri dish filled $1.5 \mathrm{~mm}$ deep with ion agar. The IR-LED (1) and 1,000-ohm resistor (3) were placed parallel to the agar surface on the outside of the wall while the wax moth larva (2) was taped to the underside of the dish.

In a series of similar experiments, a 580 -ohm resistor ( 0.5 watt) or a 290 -ohm resistor $(0.25$ watt, in series with $780 \mathrm{ohms})$ at 12 volts was taped in the same approximate position as the wax moth larva. Also, a $3 \mathrm{~mm}$ diam. light beam of moderate intensity was focused by a microscope condensor on the bottom of the petri dish in approximately the same position to determine if aggregation would occur relative to adjacent areas of similar size a few $\mathrm{mm}$ distant. Black electrical tape covered with beige masking tape was used to block the light (but not the heat of absorption) from the same light source, again to determine if aggregation would result.

In order to precisely measure the small temperature increases above ambient caused by the various heat sources, a digital electronic thermometer was constructed (Fig. 2). The temperature sensor is an integrated circuit (LM 334, National Semiconductor) which provides a voltage that is a linear function of temperature. The voltage is adjusted to 100 


\section{TABLE 1}

Aggregation of N. carpocapsae at the periphery of an agarfilled petri dish in areas which had been heated above the ambient temperature $\left(19^{\circ} \mathrm{C}\right)$ by various heat sources under either light or dark conditions

Heat source

In light room:

IR-LED, $1 \mathrm{~mm}$ away')

IR-LED, touching ${ }^{2}$ )

1,000 -ohm resistor $\left.{ }^{3}\right)$

In dark room:

IR-LED, touching ${ }^{2}$

1,000-ohm resistor $\left.{ }^{3}\right)$
Temperature above ambient

At each heated area
Number at 10

aggregating

$\left.22,3,10^{*}\right)$

$\left.21,13^{*}\right)$

1 , rest 0

1,1 , rest 0

1 , rest 0

1) The IR-LED was in series with an 820-ohm resistor at $12 \mathrm{~V}$ and was placed $1 \mathrm{~mm}$ from the outside wall of the plastic petri dish (Fig. 1).

$\left.{ }^{2}\right)$ The IR-LED was in series with a 1,000-ohm resistor at $12 . \mathrm{V}$ and was placed next to the outside wall of the dish (Fig. 1).

3) The 1,000-ohm resistor was in series with a 390 -ohm resistor at $12 \mathrm{~V}$ and was placed next to the outside wall of the dish (Fig. 1).

*) The average number of nematodes aggregating at each type of heat source was significantly greater $(\alpha=0.05)$ than the average at corresponding non-heated areas equidistant from the central release point in the petri dish.

\section{TABLE 2}

Number of $\mathbf{N}$. carpocapsae aggregating at the periphery of an agar-filled petri dish in areas which were heated about $1^{\circ} \mathrm{C}$ above various ambient temperatures in the dark

Ambient temperature

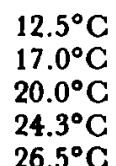

1,000-ohm Resistor ${ }^{1}$ )

$$
\begin{aligned}
& \left.18\left((13,23)^{2}\right)^{*}\right) \\
& \left.60.5(46,75)^{*}\right) \\
& \left.46.5(40,53)^{*}\right) \\
& \left.57.0(32,84)^{*}\right) \\
& \left.3.25(0,2,3,8)^{*}\right)
\end{aligned}
$$

Control areas $\overline{\mathrm{X}}$ of 10

0.3

0

0.1

0.1

1) The 1,000-ohm resistor was in series with a 390-ohm resistor at about $11 \mathrm{~V}$ (two $6 \mathrm{~V}$ batteries) and was placed next to the outside wall of the dish (Fig. 1).

$\left.{ }^{2}\right)$ Average followed by actual numbers in brackets.

*) The mean of nematodes aggregating at the heat sources was significantly greater $(\alpha=0.05)$ than the mean at corresponding non-heated areas equidistant from the central release point at the ambient temperature indicated. 


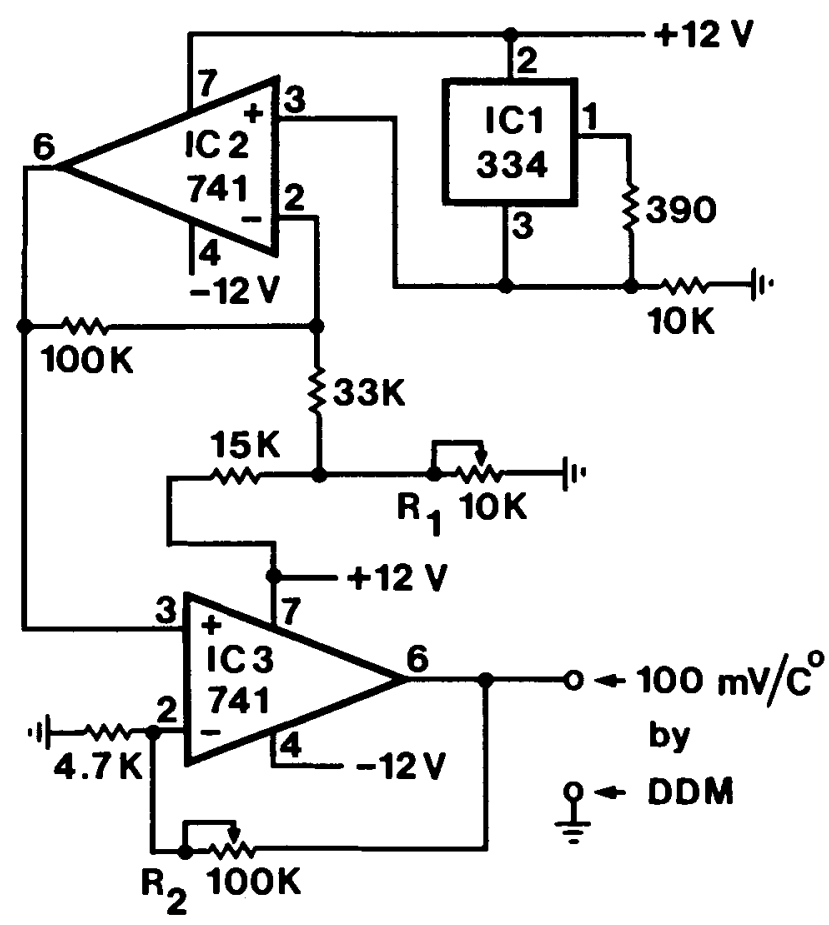

Fig. 2. Schematic diagram of electronic thermometer sensitive to $0.01^{\circ}$ from $0-20^{\circ} \mathrm{C}$ and $0.1^{\circ}$ above $20^{\circ} \mathrm{C}$. Temperature probe $\mathrm{IC} 1$ provides a voltage dependant on temperature to difference amlifier IC2. $\mathrm{R}_{1}$ is adjusted so the voltage is 0 at $0^{\circ} \mathrm{C}$. The voltage output of IC3 amplifier is adjusted via $R_{2}$ to give $100 \mathrm{mV} /{ }^{\circ} \mathrm{C}$ so that the voltage reading on a $31 / 2$ digit voltmeter (DMM) is the same as the temperature.

$\mathrm{mV} /{ }^{\circ} \mathrm{C}$ by $\mathrm{LM} 741$ op amps (Fig. 2) and the temperature is read from a DMM (digital multimeter) reading on the scale of $0-2 \mathrm{~V}\left(0-20^{\circ} \mathrm{C}\right.$ in $0.01^{\circ}$ increments) or $0-20 \mathrm{~V}$ $\left(20-50^{\circ} \mathrm{C}\right.$ in $0.1^{\circ}$ increments). The three-voltage power supply that is indicated must be regulated to provide stable voltages for the thermometer and DMM (CARR, 1978).

\section{RESULTS}

Third stage dauer juveniles of $N$. carpocapsae aggregated in response to relatively small increases of temperature $\left(0.1-0.3^{\circ} \mathrm{C}\right)$ above ambient produced by "insect-sized" heat sources in either light or dark conditions (Table 1, Fig. 3). Most of the nematodes did not move more than a few $\mathrm{mm}$ from the release point and frequently "burrowed" into the agar. The remainder of the nematodes dispersed in all directions more or less uniformly by the end of the 24 hour period. Temperature differences measured with the probe (LM 334) of the digital thermometer placed in 


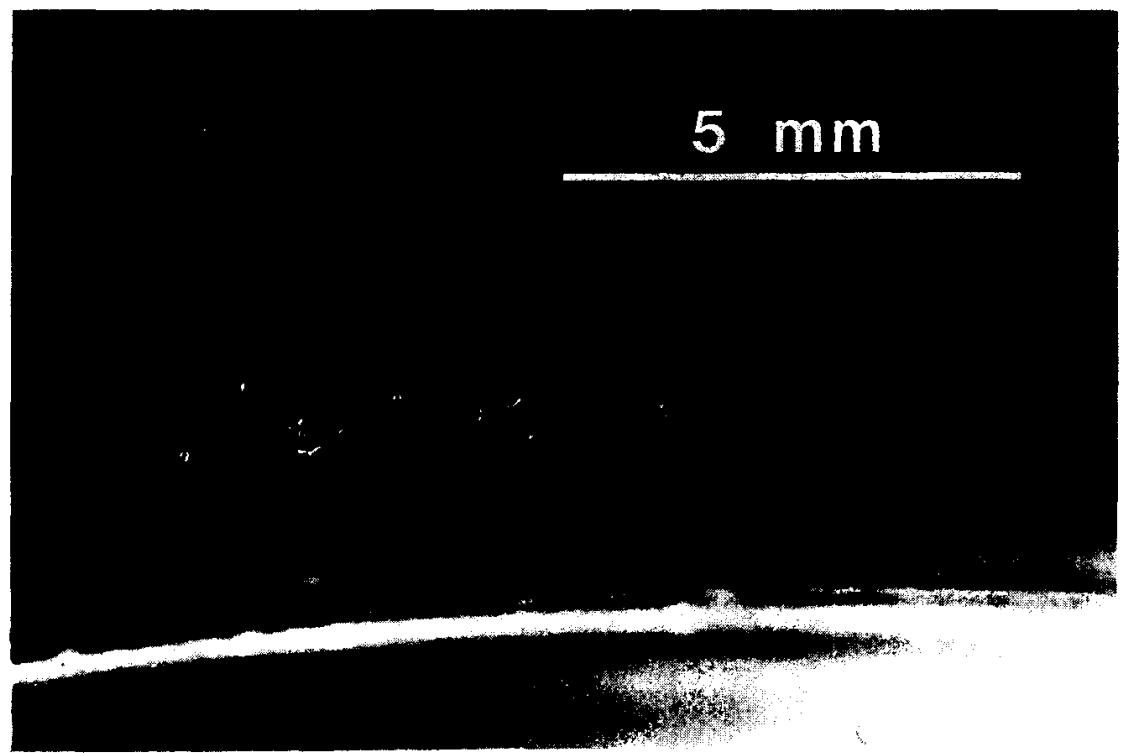

Fig. 3. Aggregation of $N$. carpocapsae in response to a temperature of $0.3^{\circ} \mathrm{C}$ above ambient at the inside wall of the petri-dish where an IR-LED was placed on the outside. The two ink spots mark the placement of the heat source before transfer for photomicrography.

the agar at the point where the heat source touched the outer wall and in nearby areas showed that heating did occur. The response of the nematodes to places with slightly higher temperatures was significantly greater than to surrounding areas at ambient temperatures from $12.5^{\circ}$ to $25.5^{\circ}$, although response at the lower and higher temperatures was diminished (Table 2).

The temperature at the surface of a wax moth larva was about $0.3^{\circ} \mathrm{C}$ above the ambient temperature while a wax moth pups was about $0.2^{\circ} \mathrm{C}$ above ambient. When wax moth larvae were placed on the bottom of the plastic petri dish, the heat conducted through the plastic into the agar was sufficient to cause aggregation of the nematodes (Fig. 4). In two replicates, averages of 18.9 and 18.5 nematodes in each of 7 and 67 quadrants above the larvae were significantly different compared to averages of 1.8 and 1.4 in each of 21 and 20 quadrants around the periphery at about $5 \mathrm{~mm}$ from the larval outline (in both cases $\mathrm{P}<0.001$ ).

Aggregations of Nematodes of 50 to 100 occurred over the 580 -ohm resistor $\left(5^{\circ}\right.$ above ambient) and the 390 -ohm resistor $\left(1.8^{\circ}\right.$ above ambient) while adjacent areas contained only a few nematodes. Similarly, 50 nematodes were found within the $3 \mathrm{~mm}$ diam. lighted area $\left(0.8^{\circ}\right.$ 


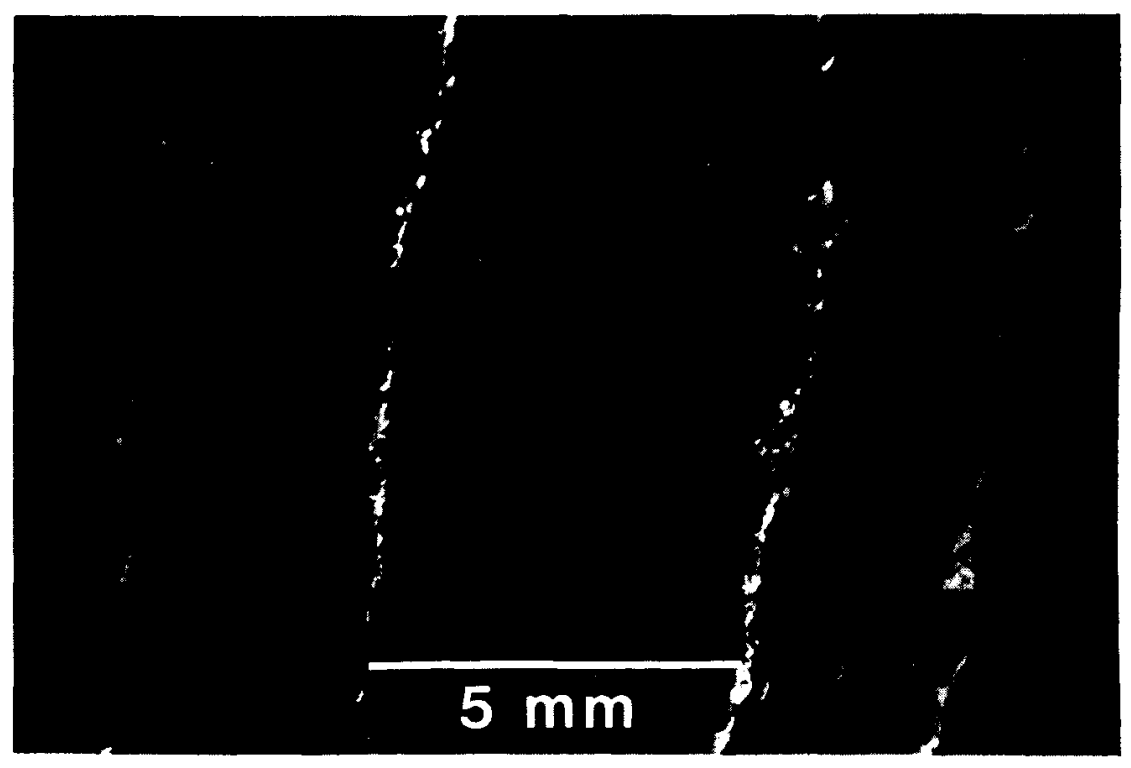

Fig. 4. Aggregation of $N$. carpocapsae in the agar-filled petri dish in response to the heat conducted from a wax moth larva $\left(<0.3^{\circ} \mathrm{C}\right)$ taped to the underside of the plastic dish. Nematodes within the inner parallel lines which indicate the approximate profile of the larval body were compared to numbers between the suter two parallel lines on either side of the larva.

above ambient) while only 1 or 2 were found in nearby areas. When the light beam was blocked by opaque tape covered with beige masking tape (only $0.2^{\circ}-0.4^{\circ}$ above ambient) then 15 nematodes were found in the 3 $\mathrm{mm}$ circle while other surrounding areas of equal size had one or no nematodes.

\section{DISCUSSION}

Our results show that $N$. carpocapsae aggregates in response to temperatures even less than $0.3^{\circ} \mathrm{C}$ above ambient which are similar to the temperatures of insects in the soil (Koidsumi in Bursell 1974) and in G. mellonella larvae. The temperatures measured by the electronic thermometer may be slightly in error due to convective heat loss from the probe. Linearity of the thermometer was expected to be about $1^{\circ}$ in error over a range of $0-50^{\circ} \mathrm{C}$ but for measurements of small temperature changes as in our study, this inherent inaccuracy $\left(<5 \%\right.$ or about $\left.0.01^{\circ}\right)$ is insignificant. The response to temperature was apparently not to a 
"preferred temperature" as has been observed in other studies (LEE \& Atkinson, 1976) since aggregation to heat sources $1^{\circ}$ above ambient occurred over a wide range of ambient temperatures. Furthermore, there was no evidence that $N$. carpocapsae "preferred" the room temperature (about $20^{\circ} \mathrm{C}$ ) at which it was reared.

Previous experiments measuring nematode behavior have sometimes confused the effects of light and heat. The apparent response of Nippostrongylus muris larvae, a vertebrate-parasitic nematode, to light was shown in fact to be a positive thermotaxis (PARKer \& Haley, 1960). The attraction of a plant parasitic nematode to light was abolished when a heat filter was added (WAllace, 1961b). Using a heat filter, Croll found that light was apparently attractive to Trichonema nematodes and that the klinokinetic responses were observed to increase with increasing light intensity. However, the nematodes could have been responding to temperature since it would be expected that light absorption by the agar and nematodes would heat the illuminated area. This in fact was shown in our study, and when light was reflected and partly absorbed by tape, $N$. carpocapsae still aggregated where the light would have been. Nippostrongylus adults accumulate at the hot end of a thermal gradient ranging from $37-48^{\circ} \mathrm{C}$ and they demonstrate a large increase in metabolism and activity near their warm-blooded hosts. This may aid the nematode in host location and need not involve sensory receptors (LEE \& ATKINSON, 1976). However, in our study $N$. carpocapsae probably has receptors sensitive to temperature since the small thermal changes associated with an insect host would not cause significant increases in the metabolism of the nematode.

Several investigations have suggested that certain nematode species find their host by random movements (SANDSTEDT \& SCHUSTER, 1962) or essentially accidentally (Peterson et al., 1967). Others contend that parasitic nematodes locate their hosts in response to host diffusates (Croll, 1970), various chemicals of a reducing (BIRD, 1959) or oxidizing nature (KLINGER, 1965). Carbon dioxide caused responses from plant (Klinger, 1965; Croll, 1970) and animal parasitic nematodes (Rogers \& Sommerville, 1963). With $N$. carpocapsae, Schmidt \& All (1978) and Pye \& Burman (1978) found that infective juveniles aggregated in response to chemical gradients diffusing from insect larvae. Gaugler et al. (1980) reported that $N$. carpocapsae oriented to $\mathrm{CO}_{2}$ released at a point source at $2-6 \mathrm{ml} / \mathrm{h}$ in an essentially two-dimensional arena consisting of an agar layer covered with a glass plate $1-1.5 \mathrm{~mm}$ above the surface. Attraction of nematodes was reported as far as $5 \mathrm{~cm}$ away at $4.1 \mathrm{ml} \mathrm{CO}_{2} / \mathrm{h}$. 
SchmidT \& All (1979), however, could not demonstrate attraction to $\mathrm{CO}_{2}$ at their lowest release rate in a system without the glass lid. However, their release rate was at least 100 times higher than GaUgLER et al. who found these rates inhibited response. It must be noted that nematodes were not attracted to air passed through a chamber containing wax moth larvae (Schmidt \& All, 1979) and Gaugler et al. did not test living insects. Based on theoretical calculation, a last instar wax moth larva weighing $0.2 \mathrm{~g}$ should release about $0.6 \mathrm{ml} \mathrm{CO} / \mathrm{h}$ (CHAPMAN, 1971) which is probably sufficient to elicit an attraction at least at "close range" in the soil. Several excretory products of insects such as uric acid, xanthine, allantoin, ammonia, and arginine diffusing onto agar were attractive to $N$. carpocapsae (50-85\% responding) (Schmidr \& AlL, 1979). However, their method of calculating percent responding tends to exaggerate the response since using their method on our results between 95 and $100 \%$ responded. In actuality, 1,000 to 2,000 nematodes were released in the present experiments but only about 20-40 aggregated at the heat source $4 \mathrm{~cm}$ away.

Our study shows that $N$. carpocapsae aggregates in response to heat conducting from an insect larva in the absence of chemical and $\mathrm{CO}_{2}$ gradients. Chemicals and $\mathrm{CO}_{2}$ diffusing from relatively immobile insects in the soil may function in "long range" attraction of nematodes over a few $\mathrm{mm}$ to several $\mathrm{cm}$ distance while thermal gradients would cause "short range" attraction over a few mm as well as arrestment at the host. Heat may also stimulate entrance of the insect's orifices. High sensitivity to thermal gradients would be ecologically adaptive for a polyphagous insect parasite such as $N$. carpocapsae. Further investigations are needed to determine if other entomogenous nematodes utilize thermal gradients as part of the mechanism of host location.

\section{SUMMARY}

1. The infective stage juveniles of Neoaplectana carpocapsae, a parasitic nematode of insects, was found to aggregate at point sources heated to temperatures of only $0.3^{\circ} \mathrm{C}$ or less above ambient in either light or dark conditions. 2. The nematode also aggregated in response to heat conducted from a wax moth larva (about $0.3^{\circ} \mathrm{C}$ above ambient) in the absence of $\mathrm{CO}_{2}$ or chemical gradients. 3 . The responses to heat sources $\left(1^{\circ}\right.$ above ambient) occurred over a wide range of ambient temperatures. 4. The apparent response of the nematode to light is at least in part caused by effects of heat from light absorption by the agar medium and nematode. 5. The response to temperature appears to function in host location especially at close range from (within a few $\mathrm{mm}$ ) the insect. 


\section{REFERENCES}

Bird, A. F. (1959). The attractiveness of roots to the plant parasitic nematodes Meloidogyne javanica and $M$. hapla. - Nematologica 4, p. 322-335.

Carr, J. (1978). How to design and build power supplies. - Pop. Electron. May, p. 61-64.

Chapman, R. F. (1971). The insects - structure and function. - Elsevier, N.Y. 819 pp.

Croll, N. A. (1965). The klinokinetic behavior of infective Trichonema larvae in light. Parasitogy 55, p. 579-582.

- (1970). The behavior of nematodes: their activity, senses and responses. - Edward Arnold Ltd., London. 117 pp.

Gaugler, R., LeBeck, L., Nakagaki, B. Boush, G. M. (1980). Orientation of the entomogenous nematode Neoapleclana carpocapsae to carbon dioxide. - Environ. Entomol. 9, p. 649-652.

KLINGER, J. (1965). On the orientation of plant nematodes and of some other soil animals. - Nematologica 11, p. 185-199.

Koldsumi, K. (1935). In: Bursel, E. p. 19 in Rockstein "The Physiology of Insecta" Vol. II, p. 1-41. - Academic Press, N.Y.

Lee, D. L. A Atkinson, H. J. (1976). Physiology of nematodes. 2nd edition. MacMillan Press. 215 pp.

Bursell, E. (1975). Environmental aspects - temperature. - In: The Physiology of Insecta, 2nd edition (M. Rockstein, ed.). Vol. II, p. 1-41. Acadernic Press, N.Y.

Parker, J. C. Haley, A. J. (1960). Phototactic and thermotactic responses of the filariform larvae of the rat nematode Nippostronylus muris. - J. Helminth. 27, p. 95-103.

Petersen, J. J., Chapman, H. C. Woodard, D. B. (1967). Preliminary observations on the incidence and biology of a mermithid nematode of Aedes sollicilans (Walker) in Louisiana. - Mosqu. New 27, p. 493-498.

Poinar, Jr., G. O. (1979). Nematodes for biological control of insects. - CRC Press, Inc., Florida $277 \mathrm{pp}$

- Thomas, G. M. (1966). Significance of Achromobacter Nematophilus Poinar * Thомаs (Achiomobacteriaceae: Eubacteriales) in the development of the nematode DD-136 (Neoaplecana sp. Steineinematidae). - Parasitology 56, p. 385-390.

Pye, A. E. Burman, M. (1978). Neaaplectana carpocapsae: infection and reproduction in large pine weevil larvae, Hylobius abietis. - Esp. Parasitol. 46, p. 1-11.

Rocers, W. P. Sommerville, R. I. (1963). The infective stage of nematode parasites, and its significance in parasitism. - Adv. Parasitol. 1, p. 109-177.

SANDSTEDT, R. * Schuster, M. L. (1962). Liquid trapping of Meloidogyne incognila about roots in agar medium. - Phytopathology 52, p. 174-175.

Schmidt, J. A AlL, J. N. (1978). Chemical attraction of Neoapleclana carpocapsae (Nematoda, Steinernematidae) to insect larvae. - Environ. Entomol. 7, p. 605-607.

- - (1979). Attraction of Neoaplectana carpocapsae (Nematoda, Steinernematidae) to common excretory products of insects. - Environ. Entomol. 8, p. 55-61.

Thomas, G. M. * Poinar, Jr., G. O. (1979). Xenorhabdus gen. nov., a genus of entomopathogenic nematophilic bacteria of the family Enterobacteriaceae. - Int. J. Syst. Bacteriol. 29, p. 352-360.

Wallace, H. R. (1961). The orientation of Ditylenchus dipsaci to physical stimuli. Nematologica 6 , p. $222-236$

White, G. F. (1929). A method for obtaining infective nematode larvae from cultures. Science 66 , p. $302-303$. 


\section{ZUSAMMENFASSUNG}

1. Junge Tiere der Nematode Neoplectana carpocapsae, die parasitisch in Insekten sind, sammeln sich, wie wir feststellen konnten, sowohl bei Helligkeit als auch im Dunkeln an Punkten, die nicht mehr als $0,3^{\circ} \mathrm{C}$ über der Umgebungstemperatur erwärmt worden waren.

2. Auch sammelten sich die Tiere durch die erzeugte Wärme einer Wachsmottenlarve (ungefähr $0,3^{\circ} \mathrm{C}$ wärmer als die Umgebung) an, ohne das Vorhandensein von Kohlendioxyd oder chemische Gradienten.

3. Die Reaktion auf Wärmequellen $\left(1^{\circ} \mathrm{C}\right.$ mehr als die Umgebung) erstreckte sich über weite Temperaturbereiche der Umgebung.

4. Die offenbare Reaktion der Nematoden auf Licht ist zumindest teilweise auf die Wirkung der Wärme zurückzuführen, die die Lichtabsorption des Agar-Nährbodens und der Tiere verursacht.

5. Die Reaktion auf Wärme scheint besonders im Bereich von wenigen $\mathrm{mm}$ Entfernung vom Wirtstiere wirksam zu sein. 